DOI: https://doi.org/10.47264/idea.lassij/4.2.23

Vol. 4, No. 2, (July-December 2020): 294-305

Research Article

URL: https://www.ideapublishers.org/index.php/lassij

\title{
Sectarian Divide as a Cause of Protracted Conflict: A Case of Syria (2011-2018)
}

\author{
Muhammad Tayyab, Shahid Ahmad Afridi* \& Maria Hamid
}

Department of Peace \& Conflict Studies, National Defence University (NDU), Islamabad, Pakistan.

Received: June 14, 2020

Published Online: December 30, 2020

\begin{abstract}
Since the people's uprising in 2011 against the authoritarian regime of Bashar Al Assad and its oppressive policies, Syria is entangled in a long spiral of violent conflict. Though a number of factors explain the violent nature of war and its longevity, however sectarianism proved to be the most significant and the most dominant factors of all. The dominance of minority Alawite community in the country led to the discrimination against other sects especially the Sunni majority, comprising 74 percent of the total population. Such prejudices against Sunnis and other sects have pitched Syrian people against the regime which evolved into a long and sectarian civil war that dominates the Syrian society till date. Applying Protracted Social Conflict Model, this paper tries to answer the question that how sectarianism played a role in the perpetuation of the Syrian civil war during 2011-2018. Using qualitative methods of analysis, the paper endeavours to dig out the roots of the current violent conflict in the country. For data collection and analysis, secondary sources in the form of books, research articles and other internet sources have been consulted in an attempt to analyse what is unknown on the basis of what is known.
\end{abstract}

Keywords: Sectarianism, Communal Discontent, Needs Deprivation, Social Conflict, Middle East, Arab Uprising, Inherent Conflict.

\section{Introduction}

The Syrian conflict is the continuation or an extension of the Arab uprising that erupted in 2011 in Middle East, commonly known as the Arab spring. While the underlying causes of the uprising were very deep, however, the individual act of self-immolation of Muhammad $\mathrm{Bu}$ Azizi, a vendor in Tunisia- sparked the outrage of the general public against autocratic regimes across the Middle Eastern Arab world. Syrian society, like most of Middle Eastern states, is divided along the sectarian lines, where one community dominates the rest. The dominancy of the Alawite minority led to the political and economic deprivations of other sects, especially the Sunnis, mainly on the basis of their non-identical identity. Consequently, the inherent conflict in Syria transformed into an overt civil war which perpetuated for a long while. What started as street protests against the Assad's regime demanding freedom, an equal access to political representation and economic resources, turned into a violent conflict because of the repressive approach of the government. In addition to the existing denial of socio-political and economic opportunities, the brutal crackdown on protesters led to resentment and violent response. Besides the deprivations, the sectarian nature of Syrian society also invited regional players like Saudi Arabia and Iran to the conflict in the name of sectarian intervention which added fuel to the fire. Coupled with that, international powers mainly USA and Russia have 
been flexing their muscles in this war against one another for their own political and geostrategic interests.

This paper tries to analyse the sectarian fault line between Sunnis and Alawites (Shias) that became a catalyst for the conflict in Syria. The central question around which this whole discussion revolves is that whether it was the socio-political and economic deprivation that fed into the sectarian fault lines and caused the war, or was it the other way around, subsequently leading to the protraction of the conflict. This research endeavour aims at deep understanding of the conflict in Syria. It tries to find out the reasons that why it took very long in Syria when the rest of the Middle Eastern countries could not sustain public pressure and crumbled in a short span of time. The objective of this research paper is to provide an insight to the readers about the sectarian element in the Syrian civil war, which has not only resulted in the worst humanitarian crisis but also has prolonged the war in the country.

\section{Research Methodology}

This research work is qualitative in nature, as it does not involve any collection or analysis of the numerical data. Rather it tries to gather in-depth insights into the Syrian civil war and make a well-informed analysis of the situation. It is mainly concerned with finding out the inherent and latent causes of the prolonged war in Syria. A narrative approach has been followed here mostly, in an attempt to examine and analyse that how the experiences of the past have impacted the events of the present. In order to find out why the conflict in this country has perpetuated, this paper has tried to collect and interpret data mainly from the secondary sources available in the shape of books, research articles, research journals, internet sources and other relevant material. However, there are some limitation/restrictions to this study. This paper follows a time frame from 2011 to 2018 and will only be focused upon the events that took place during these eight years.

\section{Applying the Protracted Social Conflict Model}

Edward Azar, one of the pioneers of the conflict resolution, has proposed a model known as Protracted Social Conflict (PSC) Model that tries to investigate and explore such intra-state wars and conflicts. It explains how the conflict originates in a society that is divided along communal lines, be it ethnic or religious, and how a state and international powers play a role in exacerbating the conflict. According to him, the dissatisfaction of communities because of the deprivation of their basic needs on the basis of communal content ultimately leads to a protracted conflict within that society (Kara, 2018). However, the dissatisfaction is the outcome of a "complex causal chain involving the role of the state and the pattern of international linkages" (Kara, 2018). Conflicts that arise in this way are there to stay for a long time and consequently, result into the deformation of state institutions, reinforce pessimism and demoralization in the society and immobilization for practical solutions.

Edward Azar's model of protracted conflicts comprises of three main interlinked phases known as (i) Genesis, (ii) Process Dynamics, and (iii) Outcome Analysis. All of these three have their own variables which try to deeply examine a given protracted conflict. According to Azar the word 'Genesis' refers to a "set of conditions that are responsible for the transformation of nonconflictual situations into conflictual ones" (Azar, 1990). It includes the factors or variables acting as preconditions for a conflict. The second phase (Process Dynamics) include the 
variables that activate or transform a latent conflict into an active or overt conflict (Azar, 1990). The third phase or the Outcome Analysis represents the conditions that "generate and reinforce such protracted social conflicts" (Azar, 1990). The emergence and development of these interlinked factors and variables within a society serve to locate whether a conflict be categorized as a protracted one or not.

This paper attempts to make an in-depth analysis of the perpetuated characteristic of Syrian conflict through the lens of Edward Azar's PSC Model. By applying the three main phases of the PSC model on this case, it tries to investigate that why it took very long in Syria, when the rest of the sheikhdoms in the Middle East crumbled in a short span of time.

\subsection{Genesis of the Syrian Conflict}

In simple terms, the genesis of the conflict refers to the presence of a set of conditions that transform 'non-conflictual situation into a conflictual one.' Edward Azar identifies four main conditions that result into the genesis of a conflict which are communal content; human needs; reaction of the state (role of the government in dealing the conflict); and international linkages (Kara, 2018). By analysing Syrian civil war, one can readily identify that all these conditions are fulfilled.

The multi-communal structure of Syrian society fulfils the very first condition of Azar's PSC. It provides a firm base for a conflict to arise. Syria, being a Muslim majority state (about 90\%) is comprised of different ethnicities and different sects within the Muslim population. It includes Arab Muslims, Greek and Roman Christian Fellahin and a small group of Jewish community. The division on the basis of population is such that $90 \%$ are Muslim $(74 \%$ Sunni, and $16 \%$ other sects, including the Alawi, Ismailis and Druze) and 10\% Christian. A small group of Jewish community of about 4,500 is also present. Being a Sunni majority state, it is governed by an Alawi Shia minority group for almost five decades. Alawites Government enjoy the support of most of the Christian minority owing to the secular outlook of the Assad's regime, which in their view, has guaranteed them religious freedom and other minority rights. They have been supporting the government to the extent that an article published in Al Ahram reports that the official of most the churches would turn in the opposing voices in their community to the government. Edward Azar states that in a multi-communal society, when a single group or a coalition of small communal groups dominates and are unresponsive to needs of other communities, it often leads to a 'disarticulation of state and the society' and hence a fragmentation of the whole society occurs. In Syria's the domination of minorities (including the Christian) over the 74 percent majority for over a five decades calls into question a critical inquiry. It also explains that the Alawites Shia minority had developed such robust power structures that largely accommodated the likeminded minority groups to and shared powers with those who would serve their agenda.

The communal division in Syria on the basis of religion or sect is not a new phenomenon. It dates back to the Ottoman rule before the First World War. Although, Muslims whether Sunni or Shia were part of a single group called Ummah and there was no stratification as such between them at least theoretically. But practically differences existed within the political systems of Ummah. Some heterodox sects like Alawites and Ismailis were not accepted as Muslims and had been kept isolated or ostracized thus creating hatred in them against other Muslim sects. The Ottoman rule was followed by the French mandate system after France intervened in the communal conflict between Ismailis and Alawites in the 1920s and stopping 
the Alawites from attacking other communities. Their conflict was mainly motivated by 'demographic pressures' which encouraged the Alawites to take lands from the Ismailis (Balanche, 2018). It resulted in a revolt of Alawites against other communities. Thus, the infightings among the Shia factions have set a stage for French intervention, which played a crucial role in the ascendency of Alawites.

After getting independence in 1946, and the emergence of Baath party, Syria embarked upon the notion of Pan-Arabism and fought wars against Israel under the Egypt-Syria nexus. Baath party in Syria was comprised of Sunnis, Shias (Alawites, Ismailis, and Duruz), and Christians. Owing to their differences in the approach towards social issues, both the Sunnis and the Alawites suspected Baath party to be working for the goals of the other side which led to schism between them. Within this multi-communal Syrian Baath party, there emerged two groups: Arab nationalists (mainly Sunnis) and Arab regionalists (Alawites, Ismailis, Duruz and Christian). The former called for defending the Arab nation while the latter emphasized upon defending Syrian homeland and working for the amelioration of people's conditions of living. The ensuing contest between the two resulted in a series of coups and counter coups in the 1950s and 1960s. The high representation of Alawites in the military as well as in the Baath party led them to victory in the 1963, when minority (Alawites) military officers took over the reins of power in a bloody coup. The struggle for power ended with the victory of the regionalist and Hafiz Al Assad, an Alawite prominent figure, emerged as the leader of Syria.

With the ascendency of Alawites to power, Hafiz Al Assad embarked upon promoting and implementing a system based on a unique Syrian identity and secularism, "even if the official Baath Party line remained focused on Arab nationalism" (Balanche, 2018). He officially maintained the posture of Arab unity in order to unite the nationalists and regionalist in his country while covertly consolidating his position and power as well as that of his sect (Alawite). Thus, these overtures fanned sectarianism beneath the surface and in the same line, Balanche (2018) argues that sectarianism is ingrained in the political structure of Syria. Although the governance system is avowedly secular, but the discriminatory socio-political and economic structures often privilege certain sects over others (Osseiran, 2018). In all the political and administrative appointments and promotions, Alawites enjoy privilege over other sects especially the Sunnis. For the last five decades, Syria has been a hostage to socioeconomic and political inequalities. All the significant positions in the policy making institutions and, in the administration, are held by people belonging to Alawite minority while the Sunni majority and the rest have no or very limited access to power and politics. They have been marginalized mainly on the basis of their identity which is not identical with that of the ruling class. Such inequalities are not only confined to the politico-economic spheres of the country but have also affected the social interaction of these sects (Osseiran, 2018). For instance, at the lower tiers of society, the inter-religious and inter-sectarian marriages are extremely uncommon.

The latest conflict in Syria that emerged in the backdrop of the Arab uprising in 2011 throughout the Middle East was not fuelled by sectarianism in its initial days but by the sociopolitical and economic grievances "stemming from the failed economic reforms of the Bashar al-Assad regime" (Wimmen, 2016). However, it soon adopted sectarian character owing to the presence of decade old communal fault lines inherited from Ottomans and exploited by Hafez and Bashar Al Assad for strengthening their own positions. It can be said that the underlying socio-economic and political causes of the Arab uprising throughout the Middle East fed into 
the already existing communal fault lines. The cosmetic economic reforms that Assad implemented in an attempt to save his Government have further alienated the masses as those reforms mainly benefited the upper class and the Alawites. To consolidate his power and position, Assad's administration tried to reconcile the people by enforcing integration in Syria which further resulted into fragmentation of the society. Syrian population was compelled to cling to their sectarian groups either for the Socio-economic benefits or for the survival (Balanche, 2018). Hence the historic rivalries between the Sunni majority and Shia minority groups were brewing up which laid a foundation for Protracted Social Conflict. The multicommunal characteristic of Syrian society and the over-dominance of Alawites minority group at the expense of other groups validates the first characteristic of Azar's PSC.

The second variable that Azar has identified, which can lead to the breakout of a PSC, is the 'individual and communal needs.' It means that to what extent individuals need of survival and wellbeing are fulfilled. Furthermore, it examines the degree of access of an individual or a community to political institutions and economic markets. If a community is denied access to these institutions or it faces unmet human needs of survival and wellbeing, it often resort to violent means to readdress these issues. In Syria, the Governance system was such that it benefited only a particular upper class and those who had ties with the ruling elite. During Hafiz Al Assad's presidency, top positions in the government as well as in the military were awarded to Alawites 'far out of proportion' to its size and population (Devlin, 1983). Some of the root causes of the 2011 uprising in Syria were 'political repression, economic inequalities, corruption of the elite and severe drought' (Manfreda, 2019).

After assuming power in 2000, Bashar al Assad resorted to political oppression by concentrating all powers in the ruling family thus dashing hopes of reforms and freedom. Favouring one party system in the country he tried to do away with opposition to his oppressive rule and left very little room for political dissent. "Civil society activism and media freedom were severely curtailed, effectively killing the hopes of political openness and freedom for Syrians" (Manfreda, 2019). Apart from the political repression, the unequal distribution of resources coupled with unfair economic policies, the benefits of which were concentrated among those having close ties with the Government exacerbated the grievances of the poor masses. The end of subsidies and soaring prices harmed the peasants and working class. A severe drought from 2006-10 added fuel to the fire rendering farmers and agrarian class unemployed (Laub, 2019). Hence the individual primary needs of survival and wellbeing were unmet. Similarly, rampant corruption in the system fomented greater grievances of the masses. Those without money and ties with the regime were deprived of their basic civic needs which pushed them to take up arms against the regime. In all these spheres, the people belonging to Alawites or having allegiance to Assad's family enjoyed the resources and services in abundance while those belonging to other sects or who were opposed to the oppressive policies of the regime were, deprived of these facilities. Such state of affairs implied a sectarian outlook, which resulted in the uprising where the Sunnis along others pitted against the Alawite minority regime thus stretching the conflict for very long.

The third variable that leads to a PSC in a society is the role of the government and the state to deal with the grievances of the people. The socio-political and economic grievances of the Syrian people have already been discussed. The role of the regime to cope up with the issues of the people had been criminally negligible. Instead, it embarked upon the policies that curtailed political freedom and downplayed access to economic markets. Assad employed all the resources at his expense to maintain the dominance of Alawites over Sunnis and others. 
Edwards Azar mainly talks about a majority group that dominates in a society which supresses other minority communities to resist their participation in politics and hence remain in power. However, the situation in Syria stands opposite to the standard thesis. Here a minority Alawite (Shia) faction is at the helm of affairs of the state and has suppressed a Sunni majority (74\%) along other minority communities. Therefore, Syria is confronted with 'Double Minority' problem. Alawite which is a minority community in whole of Syria, is a majority group in the country's government. The Sunnis, who comprised the majority of Syrian population, are in minority in the government. Hence, the majority in the government (Alawites) dominates the minority in the government (Sunnis) and discriminates against them in their due role in government so that they may remain in power.

The fourth and one of the significant variables of PSC is the 'international linkages' or the interference of the regional and international powers. Azar explains this variable in terms of economic dependence of conflict-ridden state on the other states and a client relationship (Kara, 2018). In this way international powers dictates domestic economic and political policies of the dependant state that often go against masses thus paving way for disenchantment between the state and the society. But, in the Syrian civil war, a number of regional and international powers have been involved not because of the economic dependence but because of the sectarian nature of Syrian society involving great powers and regional powers rivalries with their binary identification and opposition. These powers, instead of resolving the conflict, have rather intensified it.

Hokayem (2012) has consistently highlighted the interplay of regional as well as international powers in Syrian conflict, which has not only contributed to the violent nature of the conflict but has also dragged on the conflict, which is still going on. The regional power struggle between Saudi Arabia and Iran for regional supremacy has clearly manifested itself in the Syrian civil war. Syrian rebels have been receiving support from Saudi Arabia and its allies like Qatar and UAE while Iran has been instrumental in providing economic as well as military support to Assad regime. Both these regional powers have aligned themselves with the opposite parties to the conflict on the basis of their sectarian outlook.

Similarly, global powers like USA and Russia and to some extent China as well have contributed greatly to prolong this war in Syria. "The material support especially from US and Russia to the opposing parties has not only intensified the conflict but also sustained it" (Hokayem, 2012). Hokayem views that the Syrian rebels embarked upon this long conflict in the hope that they would also receive the same support from the United States as did Libya against Qaddafi (Hokayem, 2012). However, they failed to garner support from the US on such a large scale as the west fears more from the rise of Sunni radicalism on the one hand. Furthermore, the opposition groups are so divided and disunited in their approach against the regime that makes it difficult for the US, Saudi Arabia and others to provide an all-out support to them to fight. Thus, it provides more space to Assad to stem the tide of the opposition. While on the other hand, the role of Russia in supporting Assad's regime has been of great significance as it successfully challenged US's efforts of overthrowing the regime. Russia blocked many international actions against Syrian Government by "vetoing proposals in the UN Security Council", and also changed the dynamics of war in Assad's favour by intervening militarily in Syria back in 2015 (Erickson, 2018). The global powers interplay in this region hints the revival of the cold war rivalry between the US and Russia (former USSR) both vying for greater influence in this oil rich region. 


\subsection{Process Dynamics and Protraction of War}

The second step of the PSC is the process or course of the conflict, which manifests itself overtly owing to the underlying causes. Causes of the latent conflict in the Syrian society have been discussed in detail in the preceding portion. In the second phase, the inherent or latent conflict is activated by three main determinants namely: Communal actions and strategies; State's response; and built-in mechanism of conflict (Kara, 2018).

Communal actions and strategies are triggered mainly by a small event which further escalates into a full-scale war in a society. In case of Syria, the triggering event was the arrest and torture of fifteen boys in the south-western city of Deraa, Syria. These students, inspired by the events and uprisings in other Arab countries, wrote on a school wall an anti-regime slogan, "The people want the fall of the regime" (Laub, 2019). Their arrest and torture sent a wave of unrest in the country where the people were already complaining, even before the uprising, about the lack of political freedom, rampant corruption and other socio-economic issues. The already disgruntled population took to the streets, protesting against the event. Protests spread and escalated across the country, where the people began to demand an end to the oppressive regime, unequal economic policies, corruption and nepotism, and raised voices for deep socioeconomic and political reforms. These actions of the community set the stage for an upcoming long civil war in the country that would soon be mainly, characterized by sectarianism.

Communal actions or strategies were soon met by the Government response in Syria. Confronted with such uprising, any regime is left with many policy options at its disposal "running from political accommodation at one end of the spectrum to coercive co-option or repression at the other end (Woodhouse, 2011)." Governments in such societies often resort to force in order to put down rebellion or sometimes go for co-option. In Syria, the regime forces mainly relied on the use of force against the protesters which further aggravated the problem. As discussed in detail in the preceding sections that Alawites, being a minority sect, had outnumbered the Sunni majority in military as well as most of the political institutions. So, it was because of these reasons that they could garner the support of army and other institutions to impose their decisions in the country. According to the human rights monitors, "Syrian army fired on unarmed protesters and carried out mass arrests, both targeting dissidents and indiscriminately sweeping up men and boys" (Laub, 2019). Extrajudicial killings and torture at the detention centres were frequently reported. The authorities cut off basic human needs like food water and medicines that resulted in the worst humanitarian crises. Furthermore, the regime adopted strategies that presented the conflict as an attempt of Sunni extremists to overthrow the Alawite Government purely based on sectarianism. Depicting the uprising as Sunni sectarianism and extremism could scare other minorities into supporting the regime. Various decisions at the regime level like bombarding Sunni populated areas and statements by the authorities attributed to the uprising like "conspiracy to sow sectarian strife" etc. are evident to the fact that how this protest was steered towards a sectarian conflict (Wimmen, 2016). The protest that erupted as against the repressive regime policies soon transformed into a sectarian conflict by many factors, which resulted in its protraction.

The last variable of Azar's PSC process dynamics is the impact of the long-term conflict on the perception and behaviours of the parties to the conflict. This variable is referred to as the 'built in mechanism of conflict' which emerges by the experiences of different communities in a society. The impact of long-term conflicts is always worst which results into negative perceptions and even worse motivation on each side. Such feeling of belligerence on the 
opposite sides are imbued with fear and past experiences owing to which every move of the opposing party is seen with great suspicion. Consequently, negative images are imprinted in the minds of the communities as well as the Government, which further solidify communal antagonism and hence perpetuate the conflict. As discussed earlier in great detail that the Syrian society is comprised of many religious communities and sects that share a historical baggage of conflicts and confrontation mainly between the Sunnis and the Shias. All these experiences of the past have solidified the communal content in the country and there exists a great trust deficit among these sects. These are the negative perceptions and motivations of these communities against one other that have perpetuated the current conflict in Syria.

\subsection{Azar's Outcomes of the War}

One of the important variables of Edward Azar's PSC is the "Outcomes of the War" in which he describes that in a protracted social conflict, there emerges no clear victor or loser but a more divided and fragmented society. The Syrian civil war which erupted as a result of the popular uprising in Middle East in 2011 and soon adopted a sectarian character is a classic example of PSC. After all these years of fighting between the Government forces and the rebel groups, Syria has become a messy quagmire of regional and international proxy wars. There is very little room for any negotiated or peaceful settlement to the conflict. A very likely scenario that would put a stop to the civil war, is a military victory of Assad regime. However, ending the conflict through the use of force would not usher into the end of violence but it would result in more disarticulation between the state and its citizens.

So far, the war in Syria has been so disastrous that it resulted in the worse humanitarian crisis the world has ever witnessed since the Second World War. More than 500,000 people have been killed and some nine million people are displaced in the country (Kabalan, 2019). According to estimates of the UN, more than thirteen million people, who are caught up in the war, are in dire need of humanitarian assistance and the numbers can soar up if the fighting continues. Furthermore, the war has a devastating impact on the economic front as well. According a World Bank report, the war in Syria has resulted in the loss of US\$226 billion in the GDP. More than ten million people lost their jobs during these eight years. A greater part of the business and economic infrastructure has been destroyed. Regional and international players are at odds with each other on the question of legitimacy in Syria. Neither has the will to provide an all-out support for the reconstruction and rehabilitation of this country. Even if the war ends, it would be a long, an arduous and challenging task to put the country back on the road to economic prosperity. So, the outcomes of this conflict have been disastrous for Syria and for the region at large.

Apart from the humanitarian and economic impacts, the protracted nature of the war has shaken the social and political foundations of Syrian state and society. Azar has proposed that a protracted conflict will lead to the deformation of state institutions and that of the society. Syrian conflict has broken down the systems and institutions, that are needed to run the state and the society, and has widen the trust gap between the rulers and the ruled. State institutions soon plunged into decay when the Alawites rose to power in the 1970s. Civil bureaucracy and other political institutions have been acting as the puppets of the regime, working to strengthen the regime rather than facilitating and improving the lives of the citizens.

The civil war in Syria proved to be a potential blow to the already decaying institutions of the 
country. For the past eight years, the war has weakened the once all-powerful institution, the Syrian Army, to the extent that there remains little difference between the army and the opposition forces. Today, it consists of 'dizzying array' of local militias owing their allegiance to various factions of the society supported and sponsored by domestic and foreign actors. These small fiefdoms, nominally aligned with the regime, are actually busy in a localized war in order to protect their own communities. Much more than the other explanations, this fragmentation in the ranks of military is the direct consequence of the sectarian discontent that lies at the heart of all the problems in Syria. The war has resulted in the deformation of the state institutions and has exposed the fragility of the regime. With the fragmentation in the state forces, Assad has become to represent the regime's last pillar fighting a brutal war against his own people.

There is no effective and viable solution to the conflict visible in the near future. The sectarian nature of the conflict coupled with the involvement of the regional and international players has exacerbated the issues and resulted into its protraction.

\section{Discussion and Findings}

By analysing the existing literature on the Syrian conflict, different explanations emerge which try to identify the underlying factors that perpetuated the conflict for such a long period. Luis Losada Simon Ricart links the roots of the current conflict to history. In his research article, "The current wave of sectarian conflict in the Levant is the continuation of a conflict that has existed since the earliest days of Islam" he argues that it was under the mandate of France that Syria developed sectarian division. (Ricart) However, he does not agree with the explanation that sectarianism has been the dominant factor in protracting this conflict. He analyses that the sectarian explanation of the current situation as the 'only' factor is not a plausible one. As it was not until 1973, when the Alawite were recognized as a Shia faction (Ricart). Hence, he discards the notion that it is the sectarian division that has perpetuated the current conflict in Syria. He is more convinced by the intermediate rather than the underlying causes for the current violent scenario in Syria. Furthermore, certain analysts are of the view that the Assad's authoritarian style of governance actually led to the poor socio-economic conditions of the people and that it has got nothing to do with sectarian or communal affiliations. Rather they argue that it was the socio-economic and political compulsions that acted as a stimulus for triggering sectarianism, rather than the other way around (Ghufran, 2020 ).

Christopher Philips is also of the same view who explains that the current civil war in Syria and the mobilisation of masses on the basis of sect is "the result of long and short term structural, economic and socio-cultural and political factors rather than unchanging ancient animosities" (Phillips, 2015). He goes on to saying that in this war sectarian-identity is not the only factor. As of 2005, before losing influence in Lebanon, Syria was not that oriented towards sectarianism. However, with the assassination of Lebanese Prime Minister Rafic Al-Hariri, for which Syria was blamed, resultantly leading to the US sanctions against regime, Bashar ul Assad is believed to have instigated sectarian division in his country. It is believed that he facilitated movement of Sunni extremists to Iraq in an attempt to weaken US army but he was unaware of the fact that the same group would turn against his own regime (Phillips, 2015). Consequently, in addition to the underlying causes of the revolt (socio-political and economic woes of the general public), the sectarian sentiments also emerged in his country, demanding the overthrowing of Alawite minority Government and installing the Government of the majority i.e., Sunnis. 
Syria's going down into a violent and prolonged civil war is also the result of weak and divided opposition in the face of a strong and united Syrian Government and its allied forces. As Kim Hua Tan and Alirupendi Perudin write that the fragmentation in the ranks of Syrian rebels has largely contributed to the lack of a coherent strategy to fight on two fronts at the same time i.e., against Assad regime and ISIS (Tan \& Alirupendi, 2019). Firstly, the lack of coherence and unity in opposition has provided an edge to Assad's regime to consolidate his position and effectively fight against forces that tries to de-seat him. Secondly, even the seventy-four percent Sunni majority could not pose a formidable threat to the Government because neither have they had the capabilities nor the will to fight against a well-equipped and organised army which is at the latter's disposal. Landis predicted four main reasons that why Assad regime would survive the onslaught of the rebel groups. These were the military strength of the Government, divided and weak opposition, regional and global powers intervention, and economic sanctions (Landis, 2012). Even then, questions arise that why Assad failed to subdue the rebels after all these long years of war.

Furthermore, when the war in Syria broke out, a number of regional powers rushed to take part in it what sometimes calls as new "Cold War" or a new Great Game. For example, Hezbollah, a Lebanese organization has embarked upon direct confrontations against the rebels and the ISIS by supporting the Government of Bashar Al Assad. Iran has extended an outright support to the Syrian military which provides a firm and strong base to Assad's regime. Other actors such as Qatar, Saudi Arabia or Turkey are also taking part "supporting militias with pronounced sectarian elements" (Phillips, 2015). However, due to the disunity in the ranks of opposition forces, the military aid, and support from these outside states proved to be ineffective to oust decade's long oppressive regime of Bashar Al Assad.

However, by analysing the views of these and many other analysts who wrote extensively on the subject, one can understand that how this perception of sectarian conflict emerged so quickly in the early days of Syrian uprising back in 2011. Although many underlying causes were put forward, but the communal division was one of the most important factors that led to the perpetuation of the conflict and that cannot be overlooked. As Balanche (2018) reports that in the beginning there were many explanations for the outbreak of the war; various sociopolitical and geographical frustrations were put forward to explain its causes. However, the lack of 'revolutionary solidarity' among the people from different sects explains the other side of picture. The quick ascendency of sectarianism and it's gaining more significance in the conflict overshadows other main reasons (Balanche, 2018). It was this sectarian element that invited regional powers like Saudi Arabia and Iran to support opposing sides in the conflict in an attempt to further their own vested geo-political interests (Mollica, 2018). Furthermore, Syria is confronted with 'Double Minority' problem. Alawites, which is a minority community in whole of Syria, is a majority group in the Government while the Sunnis who compose the majority of Syrian populations are in a minority in the Government. Hence, it can be analysed that although sectarianism is not the only reason for the protraction of Syrian civil war, yet it is one of the most dominant ones.

\section{Conclusion}

Syrian civil war is the result of the wave of democratization and freedom that swept throughout the Middle East in 2011. Many strong regimes in the region crumbled because they could not sustain the pressure of the general public. Inspired by the events in their neighborhood, the 
people in Syria also took to the streets demanding an end to decades-long authoritarian rule of Assad's family and calling for more political freedom, equal access to economic resources and an end to corruption of the elites that had deformed the very foundations of the state's institutions. However, unlike in other Middle Eastern states (Libya, Egypt and Tunisia etc.), people in Syria were unsuccessful to overthrow Assad's regime and the protests quickly turned into a long civil war that still persists as of today.

Although sectarianism was not an exclusive driving force behind the civil war in Syria but it seems to be the most outstanding determinant today. It is true that initially it was the socioeconomic and political reasons that resulted in the people's uprising. However, the quick turn of events, that transformed the protests into a civil war, pitched the historical sectarian rivalries between Sunnis and Alawites (Shia) which resulted in the perpetuation of the conflict. Such communal fault lines within Syria invited regional powers like Saudi Arabia and Iran to exploit the situation and extend their influence in the region by supporting the rebels and the regime respectively. They also provided an opportunity to international powers to exploit the situation to their own benefits. USA in an attempt to consolidate its already declining hegemonic position and maintaining its physical presence in the region provided economic and military support to the rebels in the name of liberalization and democracy. While Russia got an excellent opportunity in this war to flex its muscles in the region and announce its resurgence after the end of the cold war. By supporting Assad's regime Russia has seriously made a dent in the US hegemonic position in the Middle East.

By applying Azar's PSC model, one can conclude that although all the variables for the conflict initiation were present in Syrian society. But the communal discord in Syria, where the Alawites having a dominant position over other sects, has been instrumental in making the war more violent and persistent. What started as a liberation movement calling for reforms, soon transformed into violent sectarian conflict, the end of which is not in sight in the near future.

\section{References}

Azar, E. E. (1990). The Management of Protracted Social Conflict: Theory and Cases. Dartmouth.

Balanche, F. (2018). Sectarianism in Syria's Civil War. The Washington Institute for Near East Policy. The Washington Institute for Near East Policy.

Demographics of Syria $\quad$ (n. $\quad$ d.). https://www.cs.mcgill.ca/ rwest/wikispeedia/wpcd/wp/d/Demographics_of_Syria.ht $\underline{\mathrm{m}}$

Devlin, J. F. (1983). Syria: Modern State in an Ancient Land. Westview.

Erickson, A. (2018, December 18). 7 basic questions about the war in Syria. The Washington Post. https://www.washingtonpost.com/news/worldviews/wp/2018/04/12/syriaexplained/

Ghufran, N. (2020, October 26). Personal interview by Mummad Tayyab.

Hokayem, E. (2012, March). Syria and its Neighbours . Survival. https://doi.org/10.1080/00396338.2012.672699

Kabalan, N. (2019, October 5). Has International Intervention Prolonged The War In Syria? Inside Over: https://www.insideover.com/politics/has-international-interventionprolonged-the-war-in-syria.html. 
Kara, S. (2018, April). A Theory of Protracted Social Conflict. https://www.researchgate.net/publication/324507082_a_theory_of_protracted_socia $\underline{\text { l_conflict }}$

Landis, J. (2012). The Syrian uprising of 2011: Why the Asad regime is likely to survive to 2013. Middle East Policy Council.

Laub, Z. (2019, October 23). Syria's Civil War: The Descent into Horror. Council on Foreign Relations. https://www.cfr.org/article/syrias-civil-war

Manfreda, P. (2019, July 3). 10 Factors that Led to Syrian Uprising. Thought Co. https://www.thoughtco.com/top-10-reasons-for-the-uprising-in-syria-2353571.

Mollica, J. D. (2018). Understaning Religious Violence. Springer Nature.

Osseiran, H. (2018, March 6). How Sectarianism can help Explain the Syrian Civil War. News Deeply. $\quad$ https://www.newsdeeply.com/syria/articles/2018/03/06/how-sectarianismcan-help-explain-the-syrian-war

Phillips, C. (2015). Sectarianism and Conflict in Syria. Third World Quarterly, 36(2), 357.

Ricart, L. L. (n.d.). The current wave of sectarian conflict in the Levant is the continuation of a conflict that has existed since the earliest days of Islam. Understanding Political Islam.

Tan , H., \& Alirupendi, P. (2019, June 12). The "Geopolitical" Factor in the Syrian Civil War: A Corpus-Based Thematic Analysis. Sage Journals. https://journals.sagepub.com/doi/full/10.1177/2158244019856729

Wimmen, H. (2016, November). Syria's Path From Civic Uprising to Civil War. Carnegie Endowment for International Peace. https://carnegieendowment.org/2016/11/22/syria-s-path-from-civic-uprising-tocivil-war-pub-66171

Woodhouse, T. H. (2011). Contemporary Conflict Resolution (3rd ed.). Polity. 